\title{
Growth evolution and phase transition from chalcocite to digenite in nanocrystalline copper sulfide: Morphological, optical and electrical properties
}

\author{
Priscilla Vasthi Quintana-Ramirez ${ }^{1}$, Ma. Concepción Arenas-Arrocena ${ }^{*}, \S$, \\ José Santos-Cruz ${ }^{3}$, Marina Vega-González ${ }^{4}$, Omar Martínez-Alvarez ${ }^{5}$, \\ Víctor Manuel Castaño-Meneses ${ }^{6}$, Laura Susana Acosta-Torres ${ }^{2}$ \\ and Javier de la Fuente-Hernández ${ }^{2}$
}

\section{Full Research Paper}

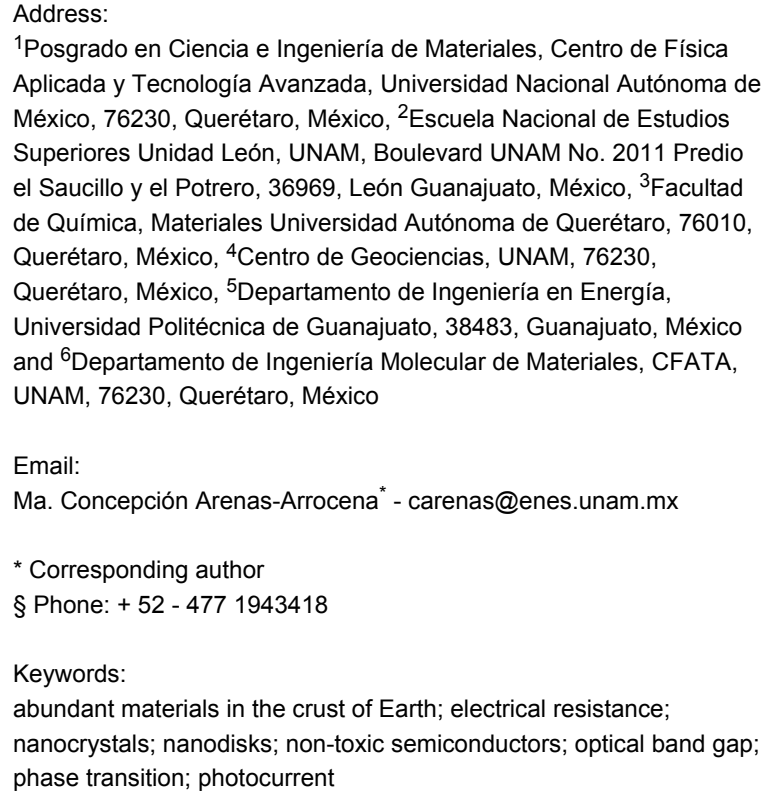

${ }^{1}$ Posgrado en Ciencia e Ingeniería de Materiales, Centro de Física Aplicada y Tecnología Avanzada, Universidad Nacional Autónoma de México, 76230, Querétaro, México, ${ }^{2}$ Escuela Nacional de Estudios Superiores Unidad León, UNAM, Boulevard UNAM No. 2011 Predio el Saucillo y el Potrero, 36969, León Guanajuato, México, ${ }^{3}$ Facultad de Química, Materiales Universidad Autónoma de Querétaro, 76010, Querétaro, México, ${ }^{4}$ Centro de Geociencias, UNAM, 76230, Querétaro, México, ${ }^{5}$ Departamento de Ingeniería en Energía, Universidad Politécnica de Guanajuato, 38483, Guanajuato, México and ${ }^{6}$ Departamento de Ingeniería Molecular de Materiales, CFATA, UNAM, 76230, Querétaro, México

\section{Email:}

Ma. Concepción Arenas-Arrocena* - carenas@enes.unam.mx

* Corresponding author

§ Phone: + 52 - 4771943418

Keywords:

abundant materials in the crust of Earth; electrical resistance;

nanocrystals; nanodisks; non-toxic semiconductors; optical band gap;

phase transition; photocurrent

\author{
Beilstein J. Nanotechnol. 2014, 5, 1542-1552. \\ doi:10.3762/bjnano.5.166
}

Received: 08 May 2014

Accepted: 26 August 2014

Published: 15 September 2014

This article is part of the Thematic Series "Physics, chemistry and biology of functional nanostructures II".

Guest Editor: A. S. Sidorenko

(C) 2014 Quintana-Ramirez et al; licensee Beilstein-Institut. License and terms: see end of document.

\footnotetext{
Abstract

Copper sulfide is a promising p-type inorganic semiconductor for optoelectronic devices such as solar cells, due its small band gap energy and its electrical properties. In this work nanocrystalline copper sulfide $\left(\mathrm{Cu}_{x} \mathrm{~S}\right)$, with two stoichiometric ratios $(x=2,1.8)$ was obtained by one-pot synthesis at $220,230,240$ and $260^{\circ} \mathrm{C}$ in an organic solvent and amorphous $\mathrm{Cu}_{x} \mathrm{~S}$ was obtained in aqueous solution. Nanoparticle-like nucleation centers are formed at lower temperatures $\left(220^{\circ} \mathrm{C}\right)$, mixtures of morphologies (nanorods, nanodisks and nanoprisms) are seen at 230 and $240{ }^{\circ} \mathrm{C}$, in which the nanodisks are predominant, while big hexagonal/prismatic crystals are obtained at $260^{\circ} \mathrm{C}$ according to TEM results. A mixture of chalcocite and digenite phases was found at 230 and $240{ }^{\circ} \mathrm{C}$, while a clear transition to a pure digenite phase was seen at $260^{\circ} \mathrm{C}$. The evolution of morphology and transition of phases is consistent to the electrical, optical, and morphological properties of the copper sulfide. In fact, digenite $\mathrm{Cu}_{1.8} \mathrm{~S}$ is less resistive (346 $\Omega /$ sq)
} 
and has a lower energy band gap $(1.6 \mathrm{eV})$ than chalcocite $\mathrm{Cu}_{2} \mathrm{~S}\left(5.72 \times 10^{5} \Omega / \mathrm{sq}, 1.87 \mathrm{eV}\right)$. Low resistivity was also obtained in $\mathrm{Cu}_{x} \mathrm{~S}$ synthesized in aqueous solution, despite its amorphous structure. All $\mathrm{Cu}_{x} \mathrm{~S}$ products could be promising for optoelectronic applications.

\section{Introduction}

Metallic chalcogenides based on cadmium, such as cadmium telluride, $\mathrm{CdTe}$, or cadmium sulfide, $\mathrm{CdS}$, have been widely investigated regarding their application in the optoelectronic field, mainly in photovoltaic devices due to the semiconducting, electronic and optical properties [1-5]. Cadmium is a toxic heavy metal, which limits its applications in the optoelectronic area. In fact, the current trend is to develop environmentfriendly nanometric semiconductors with adequate optoelectronic properties for solar cells. It is well known that all properties (physical, chemical, magnetic) of nanometric materials differ from the bulk semiconductor due to the quantum effects [6]. Among the non-toxic nanomaterials with a small energy band gap that are promising for photovoltaic devices are: iron sulfide $\left(\mathrm{FeS}_{2}\right)$, tungsten sulfide $\left(\mathrm{WS}_{2}\right)$ and copper sulfide $\left(\mathrm{Cu}_{2} \mathrm{~S}\right)$ [7]. The last is a terrestrially abundant and interesting semiconductor due to its stoichiometric variety usually depicted as $\mathrm{Cu}_{x} \mathrm{~S}$. Copper-rich sulfides $\left(\mathrm{Cu}_{2} \mathrm{~S}\right), \mathrm{Cu}_{x} \mathrm{~S}$ with $x=0.03,0.2$, 0.25 , and $\mathrm{CuS}$ are widely reported [8-27]. The stoichiometric ratio can be tailored by changing the concentration of copper or sulfide precursors, the reaction parameters and the kind of solvents. The following phases were obtained: djurleite $\left(\mathrm{Cu}_{1.97} \mathrm{~S}\right)$, digenite $\left(\mathrm{Cu}_{1.8} \mathrm{~S}\right)$ or analite $\left(\mathrm{Cu}_{1.75} \mathrm{~S}\right)$ [8-29]. These crystalline phases are stable p-type compounds, which could be used as absorber materials in solar cells [30-32]. However, the exact identification of the crystalline structure is controversial due to the stock of $86 \mathrm{XRD}$ patterns for $\mathrm{Cu}_{x} \mathrm{~S}$, some of which have reflections with narrowly spaced positions (see Table 1). This proximity makes it difficult to clearly assign diffraction patterns to certain crystalline phases.

On the other hand, the control of size, shape, distribution and stoichiometry of $\mathrm{Cu}_{x} \mathrm{~S}$ is an essential challenge nowadays, because these parameters are dependent on several factors $[12,13,15,18,21]$. For example, the reaction temperature modified the shape, size and optical properties of monodisperse $\mathrm{Cu}_{2} \mathrm{~S}$ obtained from a simple one-pot route [15]. In fact, there exists wide research about the synthesis of copper sulfide nanostructures obtaining different $\mathrm{Cu} / \mathrm{S}$ ratios $[9,11,16,20,23-26]$. However, the lack of knowledge about the growth evolution and the phase transitions of copper sulfide is the motivation of this work.

In this work, the growth evolution and the phase transition of copper sulfide in the temperature range from 220 to $260{ }^{\circ} \mathrm{C}$ in an organic solvent is reported. The full electrical, morpholog- ical and optical properties of these crystalline samples synthesized in the organic solvent were compared with the amorphous $\mathrm{Cu}_{x} \mathrm{~S}$ obtained from aqueous solution.

\section{Results and Discussion Structural properties from X-ray diffraction}

The structural properties of the copper sulfide samples $\left(\mathrm{Cu}_{x} \mathrm{~S}\right)$ depend on the synthesis and the reaction temperature (Figure 1). A fully amorphous product is obtained from aqueous solution according to the X-ray diffraction pattern (Figure S1 in Supporting Information File 1). However, the crystallinity of organic products is dependent on the temperature reaction. At $220^{\circ} \mathrm{C}, \mathrm{Cu}_{x} \mathrm{~S}$ presents three peaks with low intensity at $2 \theta=38$, 46.5 and $49^{\circ}$ corresponding to the chalcocite structure (JCPDS 31-0482) (Figure 1a). Above a temperature of $230^{\circ} \mathrm{C}$, the $\mathrm{Cu}_{x} \mathrm{~S}$ product is more crystalline. There are four peaks with broadening and better intensity at $2 \theta=37.84,46.5,48.82$, and $54.94^{\circ}$, which match both to the chalcocite (JCPDS 31-0482) phase and djurleite phase (JCPDS 20-0365). At $240{ }^{\circ} \mathrm{C}$ (Figure 1b), well defined peaks of the digenite phase $\left(\mathrm{Cu}_{1.8} \mathrm{~S}\right.$, JCPDS 47-1748) appear at 28.26, 30.02, 32.66, 42.42, 46.62, 52.32, and 55.12 corresponding to the rhombohedral structure, which is consistent to the literature [19]. Small peaks of chalcocite can be seen, which are indicative of a mixture of phases. The X-ray pattern of $\mathrm{Cu}_{x} \mathrm{~S}$ synthesized at $260{ }^{\circ} \mathrm{C}$ presents sharp peaks at $2 \theta=27.84,32.22,32.66,46.24,55.12$, and $67^{\circ}$ of the digenite phase.

Three shapes of unit cells of $\mathrm{Cu}_{2} \mathrm{~S}$ chalcocite phase can be presented: monoclinic (low chalcocite), hexagonal (high chalcocite), and cubic (cubic chalcocite) [30]. It is well known that the transformation from monoclinic $\left(\alpha, \gamma-\mathrm{Cu}_{2} \mathrm{~S}\right)$ to hexagonal $\left(\beta-\mathrm{Cu}_{2} \mathrm{~S}\right)$ occurs at $103.5^{\circ} \mathrm{C}$ and $101.8^{\circ} \mathrm{C}$ for bulk and nanostructure chalcocite, respectively [33]. According to Machani et al. [34] the monoclinic phase changes to djurleite in ambient air and the real phase obtained is djurleite instead of chalcocite, even though, the chalcocite phase is usually reported [8,12-15]. In fact, the djurleite phase is obtained in ambient air [18], while chalcocite is obtained under argon atmosphere [14]. So, the products reported here obtained at $220^{\circ} \mathrm{C}$ and $230{ }^{\circ} \mathrm{C}$ really are the chalcocite phase despite some peaks which match with djurleite. In fact, the $\mathrm{Cu}_{x} \mathrm{~S}$ products maintained the crystalline phases after we stored them for one year at room temperature, which is indicative of a good stability of the $\mathrm{Cu}_{2} \mathrm{~S}$ chalcocite and $\mathrm{Cu}_{1.8} \mathrm{~S}$ digenite phases (results not shown here). 


\begin{tabular}{|c|c|c|c|c|c|}
\hline JCPDS & $\begin{array}{l}\text { crystalline } \\
\text { structure }\end{array}$ & morphology & $\begin{array}{l}\text { position of reflections in }\left[2 \theta,{ }^{\circ}\right] \\
\text { (respective crystallographic planes) }\end{array}$ & $\begin{array}{l}\text { band gap energy } \\
E_{\mathrm{g}}(\mathrm{eV})\end{array}$ & solution/reference \\
\hline 84-0209 & $\beta-\mathrm{Cu}_{2} \mathrm{~S}$ & bulk crystals & $\begin{array}{l}37.5\left(\begin{array}{lll}1 & 0 & 2\end{array}\right) ; 45.5\left(\begin{array}{lll}1 & 1 & 0\end{array}\right) ; 48\left(\begin{array}{lll}1 & 0 & 3\end{array}\right) ; \\
54\left(\begin{array}{lll}0 & 0 & 4\end{array}\right) ; 54.5\left(\begin{array}{lll}2 & 0 & 1\end{array}\right)\end{array}$ & 1.22 & organic/[8] \\
\hline 232-0961 & ortho. $\mathrm{a}-\mathrm{Cu}_{2} \mathrm{~S}$ & films & $\begin{array}{l}27.5(180) ; 33(044) ; 47(2131) ; 51 \\
(593) ; 57(605)\end{array}$ & $2.48^{a}$ & aqueous/[9] \\
\hline $02-1294$ & ortho. $\alpha-\mathrm{Cu}_{2} \mathrm{~S}$ & $\begin{array}{l}\text { hexagonal } \\
\text { nanodisks }\end{array}$ & $\approx 38 ; \approx 46 ; \approx 48.5 ; \approx 61$ & & organic/[10] \\
\hline $84-1770$ & $\mathrm{Cu}_{2} \mathrm{~S}$ & films & 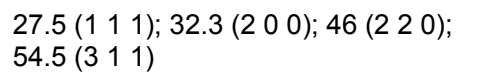 & & aqueous/[11] \\
\hline 00-0649 & $\mathrm{Cu}_{2} \mathrm{~S}$ & $\begin{array}{l}\text { hexagonal } \\
\text { nanodisks }\end{array}$ & $\approx 37.5 ; \approx 45.5 ; \approx 48.5 ; \approx 54.5$ & & organic/[12] \\
\hline $26-1116$ & hex. $\beta-\mathrm{Cu}_{2} \mathrm{~S}$ & $\begin{array}{l}\text { 14-facets } \\
\text { polyhedra }\end{array}$ & $\begin{array}{l}37.5\left(\begin{array}{lll}1 & 0 & 2\end{array}\right) ; 45.5\left(\begin{array}{lll}1 & 1 & 0\end{array}\right) ; 48\left(\begin{array}{lll}1 & 0 & 3\end{array}\right) \\
54\left(\begin{array}{lll}1 & 1 & 2\end{array}\right)\end{array}$ & $1.35-1.56^{\mathrm{b}}$ & organic/[13] \\
\hline $26-1116$ & hex. $\beta-\mathrm{Cu}_{2} \mathrm{~S}$ & $\begin{array}{l}\text { hexagonal } \\
\text { nanocrystals }\end{array}$ & 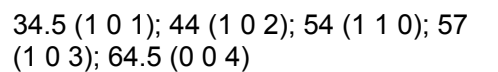 & & organic/[14] \\
\hline $26-1116$ & hex. $\beta-\mathrm{Cu}_{2} \mathrm{~S}$ & $\begin{array}{l}\text { hexagonal } \\
\text { nanodisks }\end{array}$ & 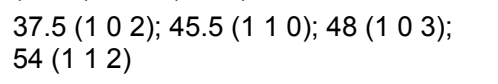 & $1.36-1.53^{b}$ & organic/[15] \\
\hline $26-1116$ & hex. $\beta-\mathrm{Cu}_{2} \mathrm{~S}$ & $\begin{array}{l}\text { hexagonal } \\
\text { nanodisks }\end{array}$ & 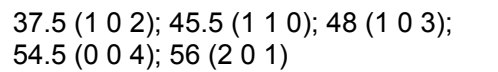 & & water-organic/[16] \\
\hline $26-1116$ & hex. $\beta-\mathrm{Cu}_{2} \mathrm{~S}$ & nanorods & 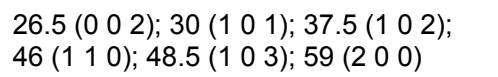 & $2.48^{a}$ & water-organic/[17] \\
\hline $29-0578$ & tet. $\mathrm{Cu}_{1.96} \mathrm{~S}$ & films & 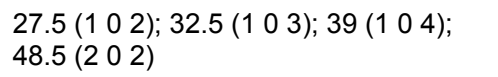 & 1.4 & aqueous/[9] \\
\hline 04-0842 & $\begin{array}{l}\text { digenite } \\
\mathrm{Cu}_{1.8} \mathrm{~S}\end{array}$ & $\begin{array}{l}\text { spherical } \\
\text { nanoparticles }\end{array}$ & $\approx 28 ; \approx 32.5 ; \approx 46.5$ & & organic/[12] \\
\hline $47-1748$ & $\begin{array}{l}\text { digenite } \\
\mathrm{Cu}_{1.8} \mathrm{~S}\end{array}$ & $\begin{array}{l}\text { irregular } \\
\text { nanoparticles }\end{array}$ & $\approx 28 ; \approx 32 ; \approx 46.5$ & & aqueous/[18] \\
\hline $47-1748$ & $\begin{array}{l}\text { digenite } \\
\mathrm{Cu}_{1.8} \mathrm{~S}\end{array}$ & $\begin{array}{l}\text { irregular } \\
\text { nanoparticles }\end{array}$ & $\approx 28 ; \approx 32 ; \approx 46.5 ; \approx 55$ & & water-organic/[19] \\
\hline 24-0061 & $\begin{array}{l}\text { digenite } \\
\mathrm{Cu}_{1.8} \mathrm{~S}\end{array}$ & films & 28 (1 11 1); 32 (2 0 0); 46 (2 20$)$ & 1.55 & aqueous/[20] \\
\hline $23-0960$ & $\begin{array}{l}\text { cub. digenite } \\
\mathrm{Cu}_{1.76} \mathrm{~S}\end{array}$ & films & 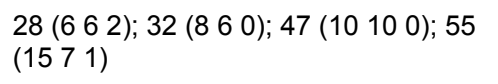 & $2.11^{a}$ & aqueous/[9] \\
\hline $00-0833$ & Cus & $\begin{array}{l}\text { spherical } \\
\text { nanoparticles }\end{array}$ & $\approx 29.5 ; \approx 32.5 ; \approx 48.5$ & & organic/[12] \\
\hline $79-2321$ & Cus & $\begin{array}{l}\text { irregular } \\
\text { nanoparticles }\end{array}$ & $29.5 ; 32 ; 48 ; 59$ & & aqueous/[18] \\
\hline $01-1281$ & hex. CuS & $\begin{array}{l}\text { clusters of } \\
\text { nanoparticles }\end{array}$ & $\begin{array}{l}29 \text { (1 } 0 \text { l 2); } 32 \text { (1 } 0 \text { 3); } 48 \text { (1 } 110) ; 52.5 \\
\left(\begin{array}{lll}1 & 0 & 4\end{array}\right) ;\end{array}$ & & aqueous/[21] \\
\hline 03-0724 & hex. CuS & nanoflowers & 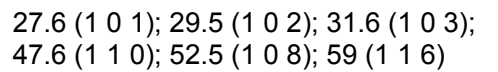 & & aqueous/[22] \\
\hline $85-0620$ & Cus & $\begin{array}{l}\text { films based on } \\
\text { nanorods }\end{array}$ & $\begin{array}{l}44 \text { (1 } 0 \text { 6); } 45 \text { (0 } 0 \text { 8); } 51 \text { (1 } 0 \text { 8); } 54 \\
(11 \text { 1 6); } 65 \text { (2 } 16) ; 75 \text { (2 } 0 \text { 8) }\end{array}$ & & aqueous/[23] \\
\hline 06-0464 & hex. CuS & films & $\begin{array}{l}29\left(\begin{array}{lll}1 & 0 & 2\end{array}\right) ; 31.5\left(\begin{array}{lll}1 & 0 & 3\end{array}\right) ; 32.5\left(\begin{array}{lll}0 & 0 & 6\end{array}\right) ; \\
48\left(\begin{array}{lll}1 & 1 & 0\end{array}\right) ; 52.5\left(\begin{array}{lll}1 & 0 & 8\end{array}\right)\end{array}$ & $1.72^{\mathrm{a}}$ & aqueous/[9] \\
\hline $06-0464$ & hex. CuS & films & 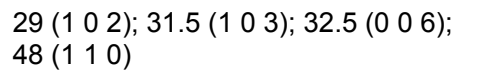 & 1.55 & aqueous/[20] \\
\hline $06-0464$ & hex. CuS & films & $\begin{array}{l}32\left(\begin{array}{lll}1 & 0 & 3\end{array}\right) ; 39.5\left(\begin{array}{lll}1 & 0 & 5\end{array}\right) ; 43.5\left(\begin{array}{lll}1 & 0 & 6\end{array}\right) ; \\
48\left(\begin{array}{lll}1 & 1 & 0\end{array}\right) ; 53\left(\begin{array}{lll}1 & 0 & 8\end{array}\right) ; 59.5\left(\begin{array}{lll}1 & 1 & 6\end{array}\right) ; \\
74.5\left(\begin{array}{lll}2 & 0 & 8\end{array}\right)\end{array}$ & 2.8 & organic/[24] \\
\hline $06-0464$ & Cus & $\begin{array}{l}\text { films based on } \\
\text { polycrystals }\end{array}$ & $\begin{array}{l}28\left(\begin{array}{lll}1 & 0 & 1\end{array}\right) ; 29\left(\begin{array}{lll}1 & 0 & 2\end{array}\right) ; 32\left(\begin{array}{lll}1 & 0 & 3\end{array}\right) 34 \\
(000) ; 48\left(\begin{array}{lll}1 & 1 & 0\end{array}\right) ; 59\left(\begin{array}{lll}1 & 1 & 6\end{array}\right) ; 59.2 \\
\left(\begin{array}{lll}1 & 0 & 6)\end{array} 52\left(\begin{array}{lll}1 & 0 & 8\end{array}\right)\right.\end{array}$ & $2^{\mathrm{a}} ; 2.58^{\mathrm{b}}$ & aqueous/[25] \\
\hline 06-0464 & hex. CuS & nanoflowers & 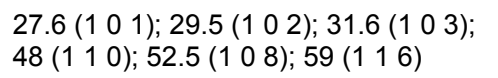 & & ethanol/[26] \\
\hline 06-0464 & hex. CuS & $\begin{array}{l}\text { irregular } \\
\text { nanoparticles }\end{array}$ & 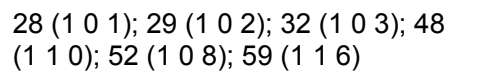 & & water-oil/[27] \\
\hline
\end{tabular}

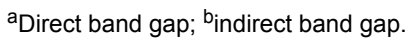



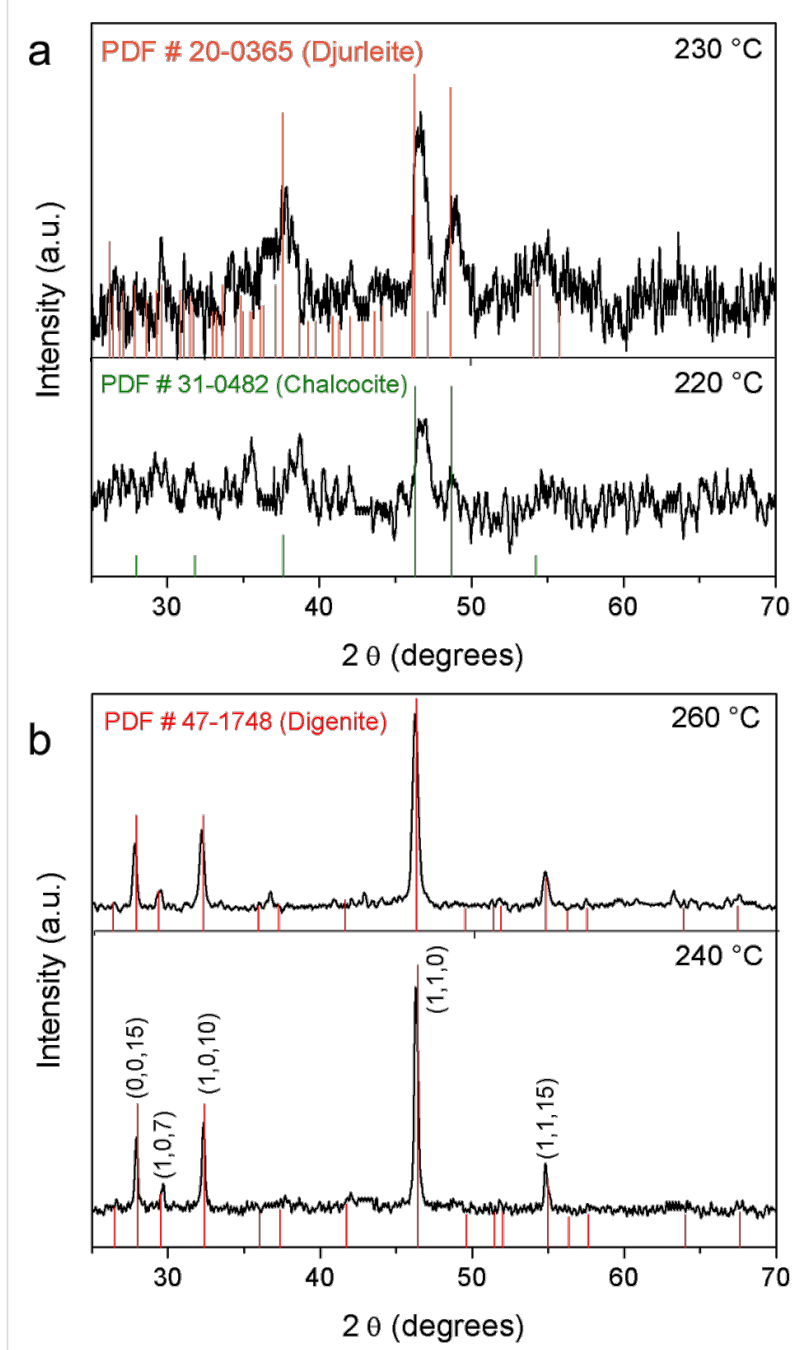

Figure 1: X-ray patterns of copper sulfide synthesized in organic solution at a) 230 and $220^{\circ} \mathrm{C}$, the chalcocite phase is obtained and at b) 240 and $260^{\circ} \mathrm{C}$, the predominant phase is the digenite.

The grain size and stress of the crystalline copper sulfide samples from organic synthesis at $230-260{ }^{\circ} \mathrm{C}$ were obtained from the full widths at a half maximum (FWHM) of the diffraction peaks and the linear combination of the following equation [35]:

$$
\frac{\beta \cos (\theta)}{\lambda}=\frac{1}{D}+\frac{\varepsilon \sin (\theta)}{\lambda},
$$

where $\beta$ is the FWHM measured in radians, $\theta$ the Bragg angle of the peaks, $\lambda$ the XRD wavelength, in our case in nanometers $(\lambda=0.154 \mathrm{~nm}), D$ is the effective crystallite size, and $\varepsilon$ is the effective strain. A plot of $\beta \cos (\theta) / \lambda$ versus $\sin (\theta) / \lambda$ for all the samples gives the grain size and the strain, as shown in Figure S2 in Supporting Information File 1. The intercept is the inverse of the grain size and the slope is the strain, respectively. The grain size increases as the temperature increases (24.5 to $28.3 \mathrm{~nm}$ ), the effective strain decreases in the samples shown that the least stress was at $260{ }^{\circ} \mathrm{C}\left(-8.26 \times 10^{-5}\right)$ and the highest was at $230{ }^{\circ} \mathrm{C}\left(-2.73 \times 10^{-3}\right)$.

\section{Morphology from TEM and HRTEM}

TEM images revel that amorphous $\mathrm{Cu}_{x} \mathrm{~S}$ from aqueous solution is constituted of nanometric particles with undefined shape that are agglomerated into clusters (See Figure S3 in Supporting Information File 1), which is in concordance with $\mathrm{Cu}_{x} \mathrm{~S}$ obtained in similar aqueous systems [21].

The morphology of $\mathrm{Cu}_{x} \mathrm{~S}$ samples from organic solution depends on the reaction temperature, for example irregular particles below $10 \mathrm{~nm}$ can be observed for $\mathrm{Cu}_{x} \mathrm{~S}$ obtained at $220{ }^{\circ} \mathrm{C}$ (Figure $2 \mathrm{a}$ ). At $230{ }^{\circ} \mathrm{C}$ short chains of stacked nanorods with lengths $(l)$ and width $(w)$ of about $13.97 \pm 2.7 \times 5.86 \pm$ $1.09 \mathrm{~nm}$ (from 260 particles), are seen in Figure 2b. Some hexagonal nanodisks of about $20-40 \mathrm{~nm}$ and prisms of about $50 \mathrm{~nm}$ are also observed. At $240{ }^{\circ} \mathrm{C}$ (Figure 2c) aligned nanorods are seen with similar dimensions $(13.55 \pm 1.86 \times 5.91$ $\pm 0.75 \mathrm{~nm}$ from 130 particles) to those seen at $230{ }^{\circ} \mathrm{C}$. The size of the $\mathrm{Cu}_{x} \mathrm{~S}$ crystals at the higher temperature is not significantly different. However, the amount of crystals with a prism geometry is increased. These two types of morphology are consistent to the mixture of phases that were shown in the X-ray results. Big crystals with different sizes $(25-80 \mathrm{~nm})$ are observed for the samples of $\mathrm{Cu}_{x} \mathrm{~S}$ synthesized at $260{ }^{\circ} \mathrm{C}$ (Figure 2d) and a fewer nanorods of about $17.35 \pm 3.70 \times 6.59$ $\pm 1.27 \mathrm{~nm}$ (from 30 particles) are also seen in Figure S4 in Supporting Information File 1. The average aspect ratios $(l / w)$ of the $\mathrm{Cu}_{x} \mathrm{~S}$ nanorods are about $2.38\left(230{ }^{\circ} \mathrm{C}\right), 2.29\left(240{ }^{\circ} \mathrm{C}\right)$, and $2.63\left(260{ }^{\circ} \mathrm{C}\right)$ taken from the data of size distribution (Figure S5 in Supporting Information File 1). The change and evolution of the morphology is consistent to the transition of phase, from chalcocite to digenite.

In order to verify the full transition of the digenite phase an HRTEM analysis of the crystals was made. The distance between the lines in the HRTEM image (Figure 3) is approximately $0.32 \mathrm{~nm}$. This corresponds to the (0015) plane spacing of the digenite phase, which matches the peak of $46 \%$ of intensity in the XRD pattern shown in Figure 1b. The diffraction pattern of electrons obtained by the Fourier transformation (inset of Figure 3) shows an interplanar distance of about $0.197 \mathrm{~nm}$, close to the value $0.19644 \mathrm{~nm}$ for the (110) spacing of the digenite phase (the peak for $100 \%$ intensity in the XRD pattern).

From TEM images, it can be observed that the phase transformation occurs from 220 to $260^{\circ} \mathrm{C}$ and involves three stages: the 

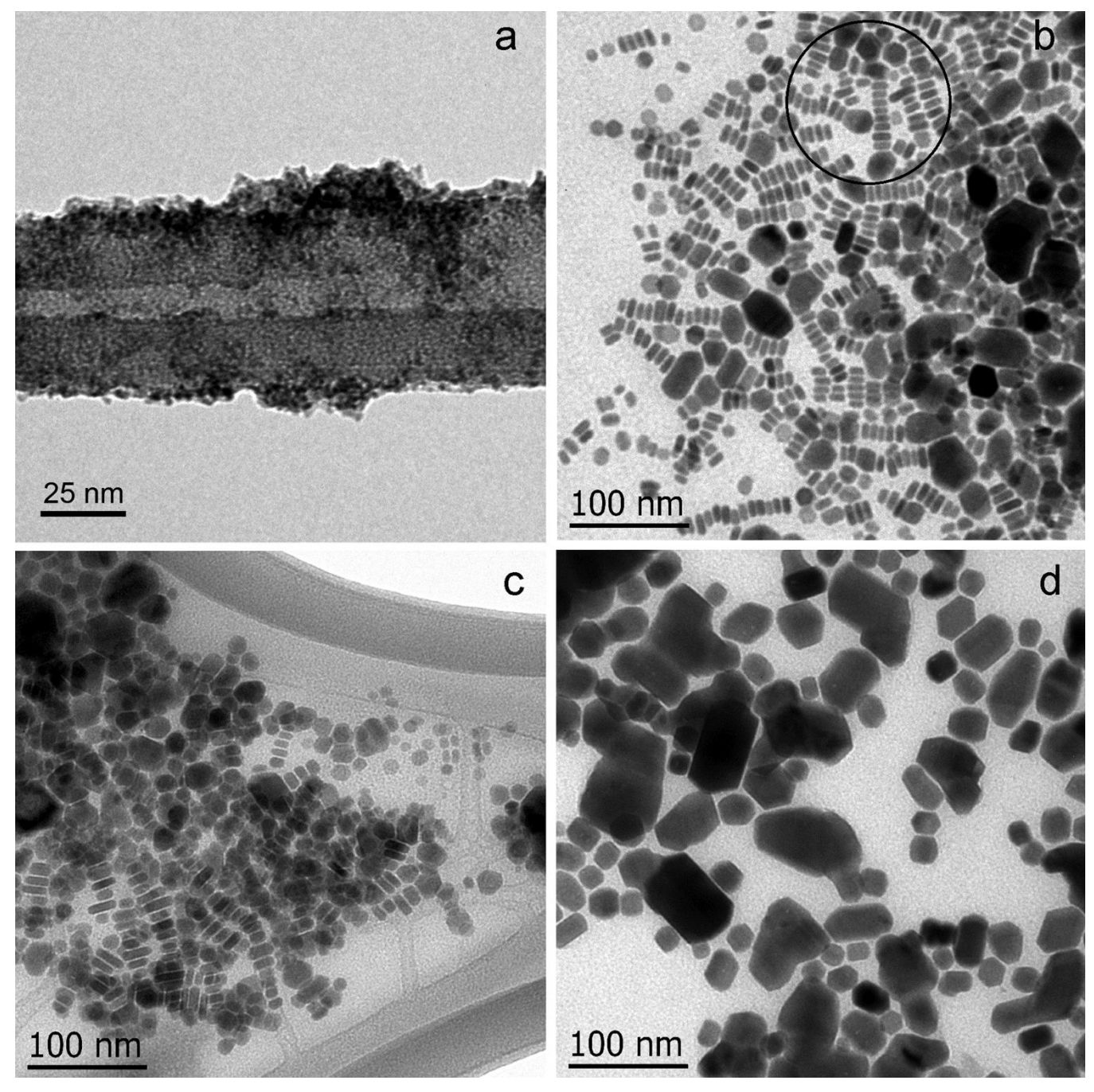

Figure 2: TEM images of copper sulfide synthesized in organic solution at a) 220 , b) 230 , c) 240 and d) $260{ }^{\circ} \mathrm{C}$. The morphology of the $\mathrm{Cu}_{x} \mathrm{~S}$ change from irregular nanoparticles to nanoprisms with increasing temperature. The encircled area shows an alignment of the nanorrods (b).

nucleation, the shape evolution of the chalcocite crystals and the transition of the chalcocite to the digenite phase. Nanoparticles are formed in the first stage at $220{ }^{\circ} \mathrm{C}$, which are the nuclei to the formation of a mixture of morphologies, i.e., nanodisks $(25-40 \mathrm{~nm})$ and irregularly shaped prisms $(50-100 \mathrm{~nm})$. The movement of the nanodisks results in the formation of the digenite phase through fusion of the nanodisks.

\section{$\mathrm{Cu} / \mathrm{S}$ ratio from EDS}

The EDS patterns shows two peaks at 0.9 and $8.0 \mathrm{keV}$ attributed to $\mathrm{Cu} \mathrm{K} \alpha$ and $\mathrm{Cu} \mathrm{L} \alpha$ emission, while a third peak at $2.3 \mathrm{keV}$ is due to the $\mathrm{S} \mathrm{K} \alpha$ emission. Table 2 displays the average of $\mathrm{Cu} / \mathrm{S}$ ratios calculated from the atomic percentage of each element from at least three measurements. The amorphous copper sulfide synthesized in an aqueous solution has a $\mathrm{Cu} / \mathrm{S}$ ratio of $1.48 \pm 0.03$, close to the $1: 1$ ratio of $\mathrm{CuS}$ [18]. The organic $\mathrm{Cu}_{x} \mathrm{~S}$ samples show the following $\mathrm{Cu} / \mathrm{S}$ ratios:
$1.58 \pm 0.02$ for the sample at $220{ }^{\circ} \mathrm{C}, 1.92 \pm 0.05$, and $1.83 \pm 0.08$ for crystalline chalcocite/digenite at 230 and $240{ }^{\circ} \mathrm{C}$, respectively, and $1.69 \pm 0.05$ for the digenite phase (at $260{ }^{\circ} \mathrm{C}$ ). These values are similar to the chalcocite $\mathrm{Cu}_{2} \mathrm{~S}$ and digenite $\mathrm{Cu}_{1.8} \mathrm{~S}$ phases, respectively.

\section{Optical properties}

The optical absorbance spectra of the $\mathrm{Cu}_{x} \mathrm{~S}$ are shown in Figure 4. Both, the amorphous sample from aqueous synthesis and the chalcocite $\mathrm{Cu}_{x} \mathrm{~S}$ from organic synthesis at $220^{\circ} \mathrm{C}$, present a weak and broad absorption band at approximately $500 \mathrm{~nm}$. However, crystalline $\mathrm{Cu}_{x} \mathrm{~S}$ samples show a welldefined absorbance band between 490 to $600 \mathrm{~nm}$. In fact, a red shift of about 40 to $60 \mathrm{~nm}$ is presented from the chalcocite $\left(\mathrm{Cu}_{2} \mathrm{~S}\right)$ to the digenite phases $\left(\mathrm{Cu}_{1.8} \mathrm{~S}\right)$, which is in agreement to the increment of crystal size. This phenomenon is related to the free charges due to the copper deficiency in the samples. For 


\begin{tabular}{|c|c|c|c|c|c|c|}
\hline $\begin{array}{l}\text { samples/temperature } \\
\left({ }^{\circ} \mathrm{C}\right)\end{array}$ & $\begin{array}{l}\text { crystalline } \\
\text { phase }\end{array}$ & $\begin{array}{l}\text { nanorod dimensions } \\
I \times w(\mathrm{~nm})\end{array}$ & $\mathrm{Cu} / \mathrm{S}$ ratio & $\begin{array}{l}\text { maximum } \\
\text { absorbance peak } \\
(\mathrm{nm})\end{array}$ & direct $E_{\mathrm{g}}(\mathrm{eV})$ & $\begin{array}{l}\text { resistance } \\
(\Omega / \mathrm{sq})\end{array}$ \\
\hline$A^{a} / 100$ & amorphous & - & $1.48 \pm 0.03$ & 530 & 2.20 & 461.50 \\
\hline $\mathrm{O}^{\mathrm{b}} / 220$ & chalcocite & - & $1.58 \pm 0.02$ & - & 1.57 & $8.66 \times 10^{6}$ \\
\hline $\mathrm{O} / 230$ & $\begin{array}{l}\text { chalcocite/ } \\
\text { digenite }\end{array}$ & $\begin{array}{l}13.97 \pm 2.7 \times 5.86 \pm \\
1.09\end{array}$ & $1.92 \pm 0.05$ & 440 & 1.87 & $5.72 \times 10^{5}$ \\
\hline $\mathrm{O} / 240$ & $\begin{array}{l}\text { chalcocite/ } \\
\text { digenite }\end{array}$ & $\begin{array}{l}13.55 \pm 1.8 \times 5.91 \pm \\
0.75\end{array}$ & $1.83 \pm 0.08$ & 480 & 1.76 & $7.29 \times 10^{7}$ \\
\hline $\mathrm{O} / 260$ & digenite & $\begin{array}{l}17.35 \pm 3.7 \times 6.59 \pm \\
1.27\end{array}$ & $1.69 \pm 0.05$ & 540 & 1.60 & 346.45 \\
\hline
\end{tabular}

asamples from aqueous solution; bsamples from organic solution.

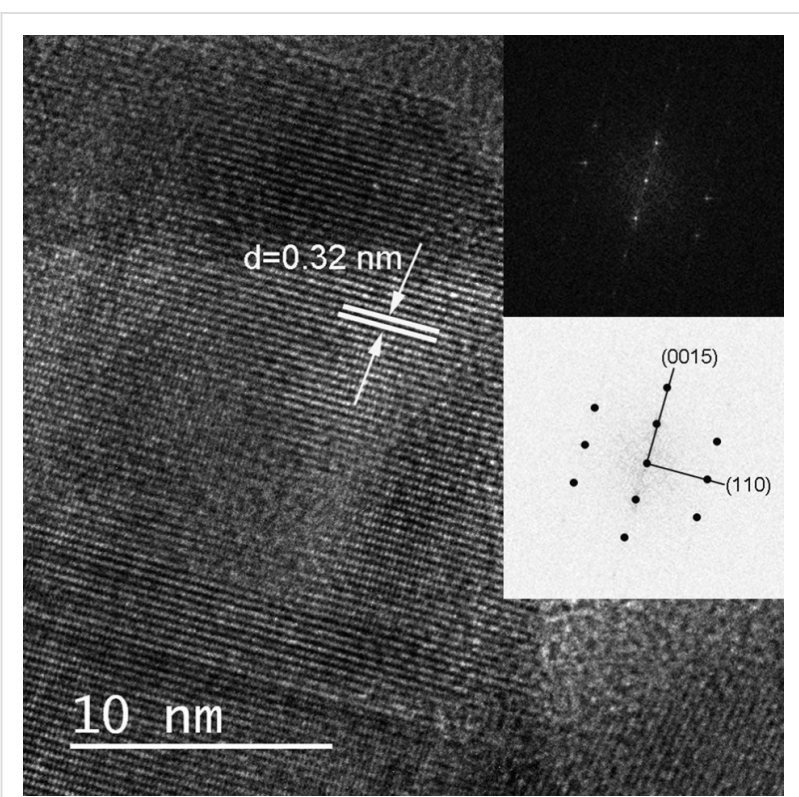

Figure 3: HRTEM image of copper sulfide obtained from synthesis in an organic solvent. The inset figures display the crystallographic planes (0015) and (110), respectively, of the digenite phase.

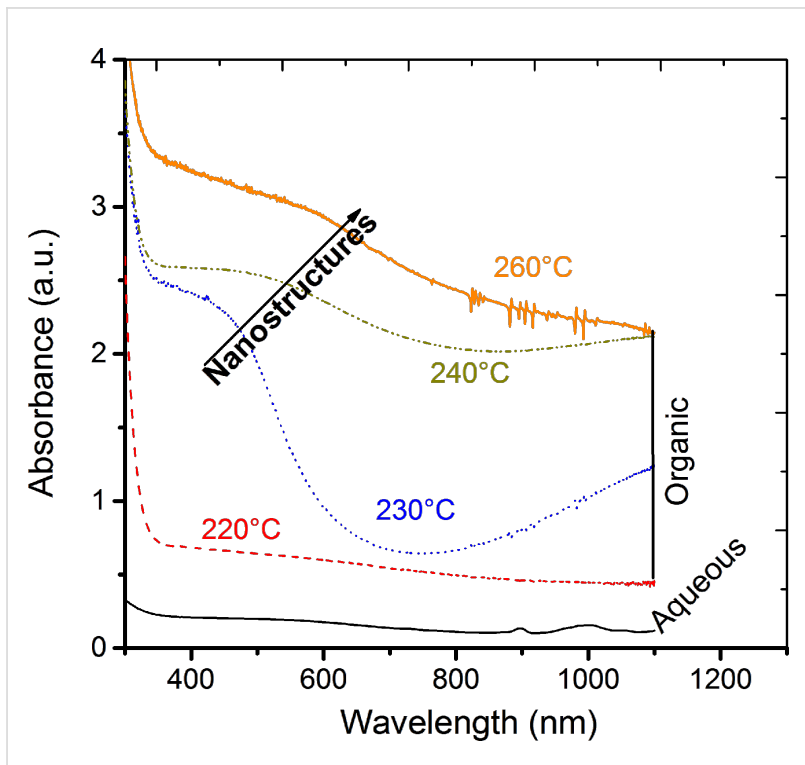

Figure 4: Absorbance of copper sulfide nanocrystals synthesized in an aqueous solution and in an organic solvent. A clear shift towards low energies is observed in the $\mathrm{Cu}_{x} \mathrm{~S}$ samples synthesized in the range from 230 to $260{ }^{\circ} \mathrm{C}$. example, the maximum absorbance band has been reported at $450 \mathrm{~nm}$ for $\mathrm{Cu}_{2} \mathrm{~S}$, while it is observed at longer wavelength $(950 \mathrm{~nm})$ for CuS [36]. It is clear, that the deficiencies of copper generate a displacement or shift of the optical absorption, which is consistent to the transition of the phases.

The energy band gaps of the samples were computed by the Tauc plot for direct transition (Figure 5). The indirect plot (inset) did not present a satisfactory straight-line region for all samples. The $\mathrm{Cu}_{x} \mathrm{~S}$ sample prepared in aqueous solution shows an $E_{\mathrm{g}}$ about $2.2 \mathrm{eV}$ for the direct and $2.0 \mathrm{eV}$ for the indirect transition, respectively (see inset of Figure 5). This is coherent with the value of $2.3 \mathrm{eV}$ reported for crystalline or amorphous $\mathrm{CuS}$ covellite thin films from an aqueous solution [25,37].
On the other hand, the direct $E_{\mathrm{g}}$ values of the $\mathrm{Cu}_{x} \mathrm{~S}$ samples prepared in the organic solvent are in the range of $1.57-1.87 \mathrm{eV}$. These values are adequate for an optical absorption in the visible region, which makes the samples very promising materials for solar cell applications. In Table 2 we observe a clear decrease of $E_{\mathrm{g}}$ from 1.87 to $1.60 \mathrm{eV}$ from crystalline chalcocite to the digenite phase, which is in agreement to the increasing crystal size observed with TEM. These values are slightly smaller to those reported for bulk copper sulfide (1.7 and $2.0 \mathrm{eV}$ ) [38], so, it is consistent to the size of the nanostructures. On the other hand, an effect was found for chalcocite crystals, namely a shift into the UV region was observed and consequently, large $E_{\mathrm{g}}$ values were obtained at high deposition times without modifying the chalcocite phase [13]. 


\section{a}
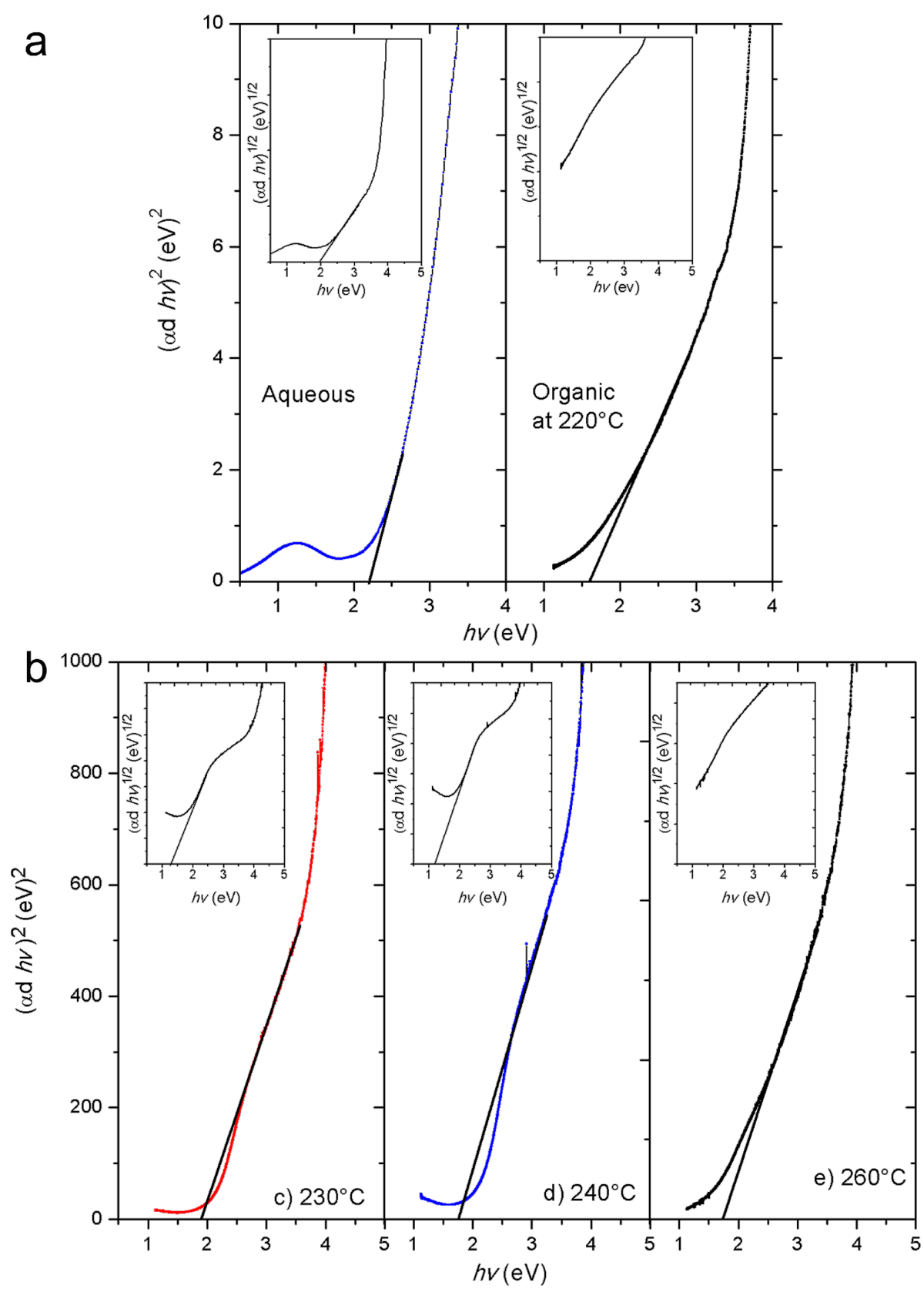

Figure 5: Direct band gaps of copper sulfide in a) amorphous phase obtained by aqueous synthesis and b) crystalline phases from organic media. Indirect band gap plots are included as an inset in all plots. The clear slopes in the graphics show the direct band gap energy.

\section{Electrical properties}

The $\mathrm{Cu}_{x} \mathrm{~S}$ films prepared in aqueous solution are amorphous with undefined morphology. They exhibit a low square electrical resistivity (about $10^{3} \Omega / \mathrm{sq}$ ) as shown in Figure 6. Chalcocite $\mathrm{Cu}_{x} \mathrm{~S}$ from organic solution has a resistance of the order of $10^{5}-10^{6} \Omega / \mathrm{sq}$, while crystalline $\mathrm{Cu}_{x} \mathrm{~S}$ has a resistivity of about $10^{7} \Omega /$ sq at $240{ }^{\circ} \mathrm{C}$ and $10^{2} \Omega /$ sq at $260^{\circ} \mathrm{C}$, respectively. In fact, the samples obtained at 230 and $240{ }^{\circ} \mathrm{C}$, which consist of a mixture of chalcocite and digenite phases, are more resistive than the digenite phase (sample at $260^{\circ} \mathrm{C}$ ). This means that the copper deficiency improves the conductivity of the $\mathrm{Cu}_{x} \mathrm{~S}$, which is consistent to the reports in the literature [20]. Deficient copper structures like analite $\left(\mathrm{Cu}_{1.75} \mathrm{~S}\right)$ have been grown onto the surface of $\mathrm{CuS}$ thin films, which improved their conductivity [28].

The time-photo-current response of $\mathrm{Cu}_{x} \mathrm{~S}$ is reported for the first time (Figure 7). It is clear that the amorphous $\mathrm{Cu}_{x} \mathrm{~S}$ presents a low photosensitivity in contrast to the crystalline $\mathrm{Cu}_{x} \mathrm{~S}$ samples obtained from organic solution, which are 


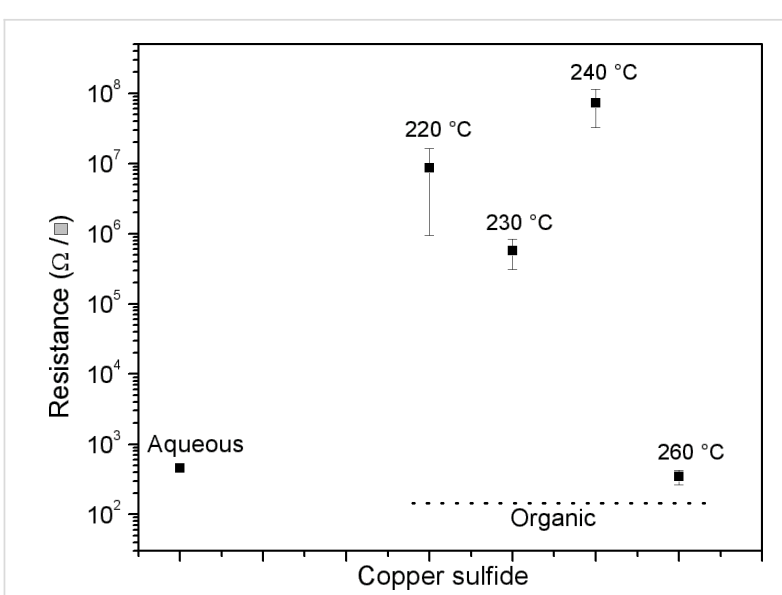

Figure 6: Square resistance of copper sulfide films synthesized in an aqueous solution (left) and in organic solution (right). The samples with low electrical resistance are amorphous $\mathrm{Cu}_{x} \mathrm{~S}$ obtained from aqueous solution and crystalline $\mathrm{Cu}_{x} \mathrm{~S}$ synthesized at $260^{\circ} \mathrm{C}$.

slightly photosensible, suggesting a photo-generation of carrier charges. The current increases gradually as a function of the time exposed to the light, this is attributed to the recombination of charges due to the superficial states in the $\mathrm{Cu}_{\mathrm{x}} \mathrm{S}$ samples.

\section{Mechanism of the formation and phase tran- sition}

According to the results presented above, a formation mechanism of the growth and the phase transition from chalcocite to

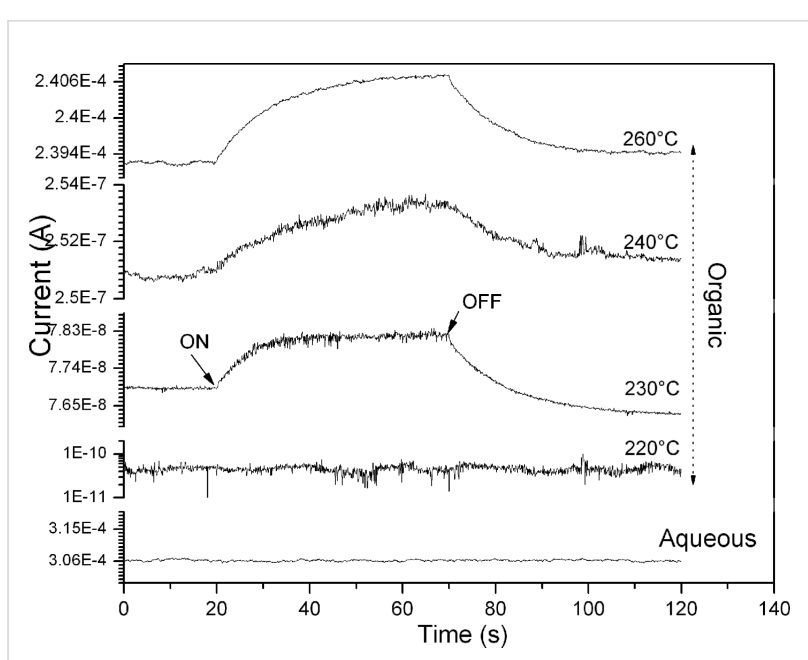

Figure 7: Photoconductivity of copper sulfide films, synthesized in both aqueous and organic media. Only the organic samples show photoconductivity.

digenite is proposed (Figure 8). It is clear that the nucleation of the crystals begins at $220^{\circ} \mathrm{C}$. It is a key to ensure the growth of nanoparticles at initial stages of the reaction. Above this temperature chains of aligned nanorods are formed and other crystals, nanodisks and prisms, grow. The chains of nanorods are predominant at $230{ }^{\circ} \mathrm{C}$ while nanodisks and prisms are the main morphology at $240{ }^{\circ} \mathrm{C}$. A full phase transition from chalcocite to digenite is obtained at $260{ }^{\circ} \mathrm{C}$.

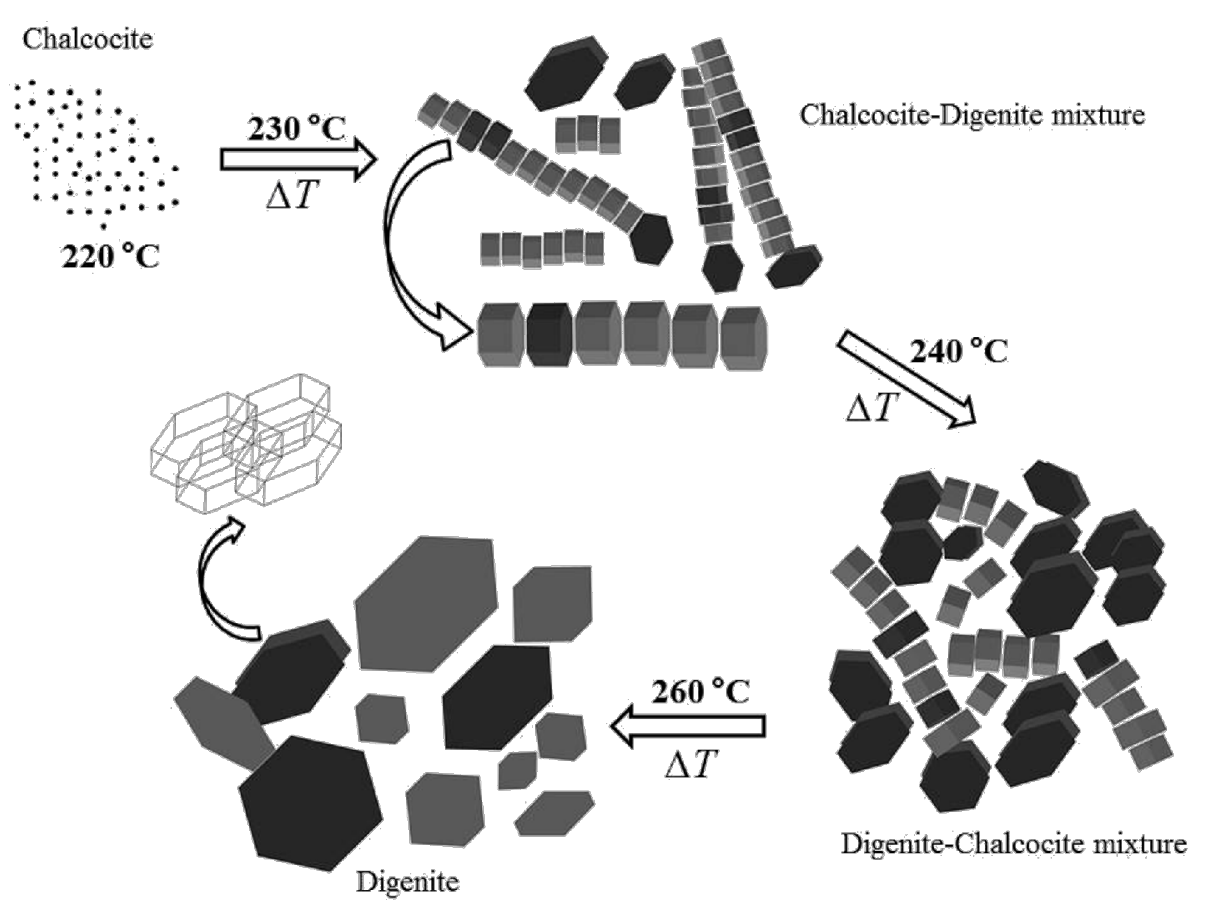

Figure 8: Scheme of the phase-transition mechanism from chalcocite to digenite and the formation of the respective nanocystals of the $\mathrm{Cu} \mathrm{u}_{x} \mathrm{Samples}$ as a function of the temperature. The growth of the crystalline digenite begins with the formation the nanoparticles at $220^{\circ} \mathrm{C}$ and it ends at $260{ }^{\circ} \mathrm{C}$. 
Wang et al. obtained nanodisks of chalcocite $\mathrm{Cu}_{2} \mathrm{~S}$ at $220{ }^{\circ} \mathrm{C}$ [15]. But, in our case, this temperature is the first stage to the phase transformation from the chalcocite to the digenite phase. According to Wang et al., the growth and rearrangement of the nanodisks are dependent on the concentration of precursors, amount of surfactant, the reaction temperature, and the reaction time. We found that this rearrangement of nanodisks is necessary for the transition of the digenite phase and it is induced only by the temperature.

On the other hand, the amorphous structure of $\mathrm{Cu}_{x} \mathrm{~S}$ prepared from aqueous solution is consistent to its synthesis at low temperatures [37], during which the $\mathrm{CuS}$ crystalline covellite phase can be formed above $200{ }^{\circ} \mathrm{C}[24,25]$, and the tailoring of the $\mathrm{Cu} / \mathrm{S}$ stoichiometric ratio and the phase transformation had been reached at temperatures between 230 to $700{ }^{\circ} \mathrm{C}$ [21]. Grozdanov and Najdoski found that the electrical sheet resistance decreases as the copper content decreased [25]. This is consistent with our results.

\section{Conclusion}

Copper sulfide with 2 and 1.8 of $\mathrm{Cu} / \mathrm{S}$ ratio were synthesized successfully from chemical synthesis in an organic solvent at 220-260 ${ }^{\circ} \mathrm{C}$. Amorphous $\mathrm{Cu}_{x} \mathrm{~S}$ was also obtained from aqueous solution at low temperatures with a low electrical resistance, indicative of a high conductivity. The evolution growth, formation of nanostructures, and phase transition were completely described in a scheme based on the TEM images. The full phase transition from chalcocite to digenite is obtained at $260{ }^{\circ} \mathrm{C}$ in an organic media. It is clear that the optical and electrical properties are suitable for optoelectronic applications, such as solar cells.

\section{Experimental}

Crystalline copper sulfide nanostructures were obtained by onepot synthesis in an organic solvent while raising the reaction temperature from 220 to $260^{\circ} \mathrm{C}$. Amorphous copper sulfide was also synthesized by a chemical reaction in aqueous solution at $40{ }^{\circ} \mathrm{C}$. Films, colloid and powder products were obtained from both reactions.

\section{Reagents}

For the organic reaction: copper(I) acetate $\left(\mathrm{C}_{2} \mathrm{H}_{3} \mathrm{CuO}_{2}\right.$, SigmaAldrich, 97\%), tri- $n$-octylphosphine oxide $\left(\mathrm{OP}\left(\mathrm{C}_{8} \mathrm{H}_{17}\right)_{3}\right.$, TOPO Sigma-Aldrich, $\geq 98 \%)$, 1-dodecanethiol $\left(\mathrm{C}_{12} \mathrm{H}_{25} \mathrm{SH}\right.$, Aldrich, $\geq 98 \%$ ), and dichlorobenzene $\left(\mathrm{C}_{6} \mathrm{H}_{4} \mathrm{Cl}_{2}\right.$, Sigma-Aldrich 99\%) were used as received.

The aqueous reaction: deionized water $(10 \mathrm{M} \Omega \cdot \mathrm{cm})$, thiourea $\left(\mathrm{H}_{2} \mathrm{NCSNH}_{2}\right.$, Aldrich $\left.\geq 99 \%\right)$, copper(II) sulfate pentahydrate $\left(\mathrm{CuSO}_{4} \cdot 5 \mathrm{H}_{2} \mathrm{O}\right.$, Baker $\left.99.3 \%\right)$, triethanolamine (TEA,
$\mathrm{C}_{6} \mathrm{H}_{15} \mathrm{NO}_{3}$, Baker 99.8\%), and sodium acetate $\left(\mathrm{NaCOOCH}_{3}\right.$, Baker, 99.5\%)

\section{Synthesis of nanocrystalline copper sulfide from organic solvent}

It consisted of a one-pot colloidal process previously reported by Wang et al. [15] with slight modifications. In this reaction, $\mathrm{C}_{2} \mathrm{H}_{3} \mathrm{CuO}_{2}$ was the copper precursor and $\mathrm{C}_{12} \mathrm{H}_{25} \mathrm{SH}$ the sulfur precursor. In brief, $1 \mathrm{~g}$ of TOPO and $0.0488 \mathrm{~g}$ of $\mathrm{C}_{2} \mathrm{H}_{3} \mathrm{CuO}_{2}$ were mixed with $30 \mathrm{~mL}$ of $\mathrm{C}_{18} \mathrm{H}_{36}$ in a three-neck flask. Argon was flowed into the system for 30 min to keep the reaction under an inert atmosphere. Then, the solution was heated to $160{ }^{\circ} \mathrm{C}$ and $1 \mathrm{~mL}$ of $\mathrm{C}_{12} \mathrm{H}_{25} \mathrm{SH}$ was injected quickly under vigorous stirring. The mixture reacted at constant temperature $\left(220,230,240\right.$ or $\left.260^{\circ} \mathrm{C}\right)$ during $120 \mathrm{~min}$. The colloidal brown products were washed three times with dichlorobenzene by centrifugation (20,000 rpm, $20 \mathrm{~min}$ ) and were re-dispersed in dichlorobenzene. The organic products were cast on a Corning glass substrate and dried at $60{ }^{\circ} \mathrm{C}$ in an electric grill in order to form films.

\section{Synthesis of amorphous copper sulfide from aqueous solution}

In this reaction thiourea and copper(II) sulfate pentahydrate $\left(\mathrm{CuSO}_{4} \cdot 5 \mathrm{H}_{2} \mathrm{O}\right)$ were the sulfur and copper precursors, respectively, and the TEA ligand was an intermediary in the reaction. The synthesis proceeded as follows: A three-necked reactor containing $440 \mathrm{~mL}$ of deionized water was placed on a hot plate with magnetic stirring at $40{ }^{\circ} \mathrm{C}$ for $30 \mathrm{~min}$. Clean Corning glass substrates were immersed inside the reactor in order to obtain the films by in situ deposition. Subsequently $1.3389 \mathrm{~g}$ of $\mathrm{CuSO}_{4} \cdot 5 \mathrm{H}_{2} \mathrm{O}$, previously dissolved in $20 \mathrm{~mL}$ of deionized water $(1.3389 \mathrm{~g} / 20 \mathrm{~mL}), 0.4354 \mathrm{~g} / 14.5 \mathrm{~mL}$ of $\mathrm{NaCOOCH}_{3}$ and, $5.18 \mathrm{~mL} / 20 \mathrm{~mL}$ of TEA. Finally, $0.2 \mathrm{~g} / 31 \mathrm{~mL}$ of $\mathrm{H}_{2} \mathrm{NCSNH}_{2}$ was added in three aliquots each for $25 \mathrm{~min}$. The substrates were withdrawn from the reactor and rinsed with deionized water. The precipitated products were washed with deionized water three times, immediately they were centrifuged and dried at room temperature. Both films and powder products, received a thermal treatment at $100^{\circ} \mathrm{C}$ in air in a stove during $1 \mathrm{~h}$.

\section{Characterization}

Powders of two syntheses, aqueous and organic, respectively, of $\mathrm{Cu}_{x} \mathrm{~S}$ were re-dispersed in isopropanol and toluene. One aliquot from these solutions was placed on carbon-coated copper grids for characterization by TEM, in a JEOL JEM-1010 at $80 \mathrm{kV}$ of acceleration potential. Additionally, thin films of aqueous and organic syntheses of $\mathrm{Cu}_{x} \mathrm{~S}$ were characterized by X-ray diffraction (Rigaku, MiniFlex, $\mathrm{Cu} \mathrm{K \alpha} 1.54 \AA$ and $2 \theta$ from 10 to $70^{\circ}$, rate $2 \%$ min each $0.02 \mathrm{~s}$ ), electrically by the four-points-probe technique, by UV-vis spectroscopy (Thermo Scientific Genesys 
10S UV-vis spectrophotometer in the range of 200 to $1100 \mathrm{~nm}$ ) in order to determine, the structural phase, the electrical resistance and optical absorbance spectra, respectively. The photoresponse measurements were made by applying a potential of $1 \mathrm{~V}$ at the sample: $20 \mathrm{~s}$ in darkness, $50 \mathrm{~s}$ under illumination and another $50 \mathrm{~s}$ in darkness. For this, two rectangular metallic contacts $(0.5 \times 0.2 \mathrm{~cm})$ were painted on the surface of the films with silver paint in a square sample of $0.5 \mathrm{~cm}^{2}$.

Energy dispersive X-ray spectroscopy (EDS) was carried out in a JSM-6060LV SEM at $20 \mathrm{keV}$ by using $\mathrm{KBr}$ pellets containing granules of $\mathrm{Cu}_{x} \mathrm{~S}$ powder to make the punctual analysis.

\section{Supporting Information}

\section{Supporting Information File 1}

Additional Figures.

[http://www.beilstein-journals.org/bjnano/content/

supplementary/2190-4286-5-166-S1.pdf]

\section{Acknowledgements}

This work was financed by CONACyT-México (CB176450, CB154787) and SENER-CONACyT (CeMIE-Sol project No. 27). The authors are grateful for the technical support received from Domingo Rangel, Beatriz Millán, Alicia del Real, Lourdes Palma (INB-UNAM) and Gabriel Nava (INB-UNAM). Thank to Marcela Ovalle Marroquín for her appreciable helps in HRTEM.

\section{References}

1. Xie, Y.-L. Electrochim. Acta 2013, 105, 137-141. doi:10.1016/j.electacta.2013.04.157

2. Kosyachenko, L.; Toyama, T. Sol. Energy Mater. Sol. Cells 2014, 120, 512-520. doi:10.1016/j.solmat.2013.09.032

3. Arenas, M. C.; Mendoza, N.; Cortina, H.; Nicho, M. E.; Hu, H. Sol. Energy Mater. Sol. Cells 2010, 94, 29-33. doi:10.1016/j.solmat.2009.04.013

4. Salinas, O. H.; López-Mata, C.; Hu, H.; Nicho, M. E. Sol. Energy Mater. Sol. Cells 2006, 90, 2421-2428. doi:10.1016/j.solmat.2006.03.015

5. Mathew, X.; Cruz, J. S.; Coronado, D. R.; Millán, A. R.; Segura, G. C.; Morales, E. R.; Martínez, O. S.; Garcia, C. C.; Landa, E. P. Sol. Energy 2012, 86, 1023-1028. doi:10.1016/j.solener.2011.06.024

6. Alivisatos, A. P. Science 1996, 271, 933-937. doi:10.1126/science.271.5251.933

7. Wadia, C.; Alivisatos, A. P.; Kammen, D. M. Environ. Sci. Technol. 2009, 43, 2072-2077. doi:10.1021/es8019534

8. Zhao, F.; Chen, X.; Xu, N.; Lu, P.; Zheng, J.-G.; Su, Q.; Wu, M. J. Phys. Chem. Solids 2006, 67, 1786-1791. doi:10.1016/j.jpcs.2006.02.020

9. Bagul, S. V.; Chavhan, S. D.; Sharma, R. J. Phys. Chem. Solids 2007, 68, 1623-1629. doi:10.1016/j.jpcs.2007.03.053
10. Tang, A.; Qu, S.; Li, K.; Hou, Y.; Teng, F.; Cao, J.; Wang, Y.; Wang, Z. Nanotechnology 2010, 21, 285602. doi:10.1088/0957-4484/21/28/285602

11. Lu, Y.; Yi, G.; Jia, J.; Liang, Y. Appl. Surf. Sci. 2010, 256, 7316-7322. doi:10.1016/j.apsusc.2010.05.072

12. Bera, P.; Seok, S. I. Solid State Sci. 2012, 14, 1126-1132. doi:10.1016/j.solidstatesciences.2012.05.027

13. Li, Y.; Zhang, L.; Yu, J. C.; Yu, S.-H. Prog. Nat. Sci. 2012, 22, 585-591. doi:10.1016/j.pnsc.2012.12.001

14. Wu, Y.; Wadia, C.; Ma, W.; Sadtler, B.; Alivisatos, A. P. Nano Lett. 2008, 8, 2551-2555. doi:10.1021/nl801817d

15. Wang, Y.; Hu, Y.; Zhang, Q.; Ge, J.; Lu, Z.; Hou, Y.; Yin, Y. Inorg. Chem. 2010, 49, 6601-6608. doi:10.1021/ic100473e

16. Zhang, P.; Gao, L. J. Mater. Chem. 2003, 13, 2007-2010. doi:10.1039/B305584A

17. Larsen, T. H.; Sigman, M.; Ghezelbash, A.; Doty, R. C.; Korgel, B. A. J. Am. Chem. Soc. 2003, 125, 5638-5639. doi:10.1021/ja0342087

18. Zhao, Y.; Pan, H.; Lou, Y.; Qiu, X.; Zhu, J.; Burda, C. J. Am. Chem. Soc. 2009, 131, 4253-4261. doi:10.1021/ja805655b

19. Leidinger, P.; Popescu, R.; Gerthsen, D.; Lünsdorf, H.; Feldmann, C. Nanoscale 2011, 3, 2544-2551. doi:10.1039/c1nr10076a

20. Nair, M. T. S.; Guerrero, L.; Nair, P. K. Semicond. Sci. Technol. 1998, 13, 1164-1169. doi:10.1088/0268-1242/13/10/019

21. Kristl, M.; Hojnik, N.; Gyergyek, S.; Drofenik, M. Mater. Res. Bull. 2013, 48, 1184-1188. doi:10.1016/j.materresbull.2012.12.020

22. Ding, T.-Y.; Wang, M.-S.; Guo, S.-P.; Guo, G.-C.; Huang, J.-S. Mater. Lett. 2008, 62, 4529-4531. doi:10.1016/j.matlet.2008.08.031

23. Dhasade, S. S.; Patil, J. S.; Han, S. H.; Rath, M. C.; Fulari, V. J. Mater. Lett. 2013, 90, 138-141. doi:10.1016/j.matlet.2012.09.013

24. Maji, S. K.; Mukherjee, N.; Dutta, A. K.; Srivastava, D. N.; Paul, P.; Karmakar, B.; Mondal, A.; Adhikary, B. Mater. Chem. Phys. 2011, 130, 392-397. doi:10.1016/j.matchemphys.2011.06.057

25. Grozdanov, I.; Najdoski, M. J. Solid State Chem. 1995, 114, 469-475. doi:10.1006/jssc.1995.1070

26. Zou, J.; Jiang, J.; Huang, L.; Jiang, H.; Huang, K. Solid State Sci. 2011, 13, 1261-1267. doi:10.1016/j.solidstatesciences.2011.03.019

27. Jiang, D.; Hu, W.; Wang, H.; Shen, B.; Deng, Y. Colloids Surf., A 2011, 384, 228-232. doi:10.1016/j.colsurfa.2011.03.053

28. Liufu, S.-C.; Chen, L.-D.; Yao, Q.; Huang, F.-Q. J. Phys. Chem. C 2008, 112, 12085-12088. doi:10.1021/jp805029w

29. Pattrick, R. A. D.; Mosselmans, J. F. W.; Charnock, J. M.; England, K. E. R.; Helz, G. R.; Garner, C. D.; Vaughan, D. J. Geochim. Cosmochim. Acta 1997, 61, 2023-2036. doi:10.1016/S0016-7037(97)00061-6

30. Xu, Q.; Huang, B.; Zhao, Y.; Yan, Y.; Noufi, R.; Wei, S.-H. Appl. Phys. Lett. 2012, 100, 061906. doi:10.1063/1.3682503

31. Isac, L.; Duta, A.; Kriza, A.; Manolache, S.; Nanu, M. Thin Solid Films 2007, 515, 5755-5758. doi:10.1016/j.tsf.2006.12.073

32. Lu, Y.; Hou, Y.; Wang, Y.; Feng, Z.; Liu, X.; Lü, Y. Synth. Met. 2011, 161, 906-910. doi:10.1016/j.synthmet.2011.02.023

33. Wang, S.; Guo, L.; Wen, X.; Yang, S.; Zhao, J.; Liu, J.; Wu, Z. Mater. Chem. Phys. 2002, 75, 32-38. doi:10.1016/S0254-0584(02)00026-3

34. Machani, T.; Rossi, D. P.; Golden, B. J.; Jones, E. C.; Lotfipour, M.; Plass, K. E. Chem. Mater. 2011, 23, 5491-5495. doi:10.1021/cm2022196

35. Quadri, S. B.; Skeleton, E. F.; Hsu, D.; Dinsmore, A. D.; Yang, J.; Gray, H. F.; Ratna, B. R. Phys. Rev. B 1999, 60, 9191-9193. doi:10.1103/PhysRevB.60.9191 
36. Solanki, J. N.; Sengupta, R.; Murthy, Z. V. P. Solid State Sci. 2010, 12, 1560-1566. doi:10.1016/j.solidstatesciences.2010.06.021

37. Güneri, E.; Kariper, A. J. Alloys Compd. 2012, 516, 20-26. doi:10.1016/j.jallcom.2011.11.054

38. Liu, G.; Schulmeyer, T.; Brötz, J.; Klen, A.; Jaegermann, W. Thin Solid Films 2003, 431-432, 477-482. doi:10.1016/S0040-6090(03)00190-1

\section{License and Terms}

This is an Open Access article under the terms of the Creative Commons Attribution License

(http://creativecommons.org/licenses/by/2.0), which permits unrestricted use, distribution, and reproduction in any medium, provided the original work is properly cited.

The license is subject to the Beilstein Journal of

Nanotechnology terms and conditions:

(http://www.beilstein-journals.org/bjnano)

The definitive version of this article is the electronic one which can be found at: doi:10.3762/bjnano.5.166 